\title{
Synergistic effect of organic amendments and biostimulants on faba bean grown
}

\section{under sandy soil conditions}

\author{
Mohamed S. Abbas ${ }^{1 *} \odot$, Ramadan A. Badawy ${ }^{2}$, Hashim M. Abdel-Lattif ${ }^{\oplus}$, Hattem M. El-Shabrawi ${ }^{3} \odot$
}

${ }^{1}$ Cairo University/Faculty of African Postgraduate Studies

- Natural Resources Dept., El-Gamaa Street, 12631 - Giza

- Egypt.

${ }^{2}$ Cairo University/Faculty of Agriculture - Agronomy Dept., El-Gamaa Street, 12631 - Giza - Egypt.

${ }^{3}$ National Research Centre - Plant Biotechnology Dept., El

Buhouth Street, 12622 - Cairo - Egypt.

*Corresponding author <msaelsarawy@yahoo.com>

Edited by: Mohammad Bagher Hassanpouraghdam

Received September 20, 2020

Accepted January 23, 2021
ABSTRACT: A combination of abiotic stresses in sandy soils, such as saline water, saline soil, and lack of nutrients, affects productivity of faba bean. In this study, organic amendments and biostimulants (VIUSID ${ }^{\circledR}$ agro) were used in combination to increase yield of faba bean seed as well as the protein content under a sandy soil and irrigation affected by salt water. Two field experiments were carried out during two successive winter seasons of 2016/2017 and $2017 / 2018$. A split-split-plot design in a randomized complete block was used. The main plots were allotted to the organic amendments, rates of biostimulants (VIUSID ${ }^{\circledR}$ agro) were assigned to sub-plot, and the cultivars were applied to sub-sub-plot. The results showed that the treatment of plant compost applied as an organic amendment and $1.5 \mathrm{~L} \mathrm{ha}^{-1}$ of biostimulants (VIUSID ${ }^{\circledR}$ agro) with foliar application significantly increased seed yield of cultivars, Sakha-4, Sakha-1, and Giza-843 by 17.2, 33.0, and $19.8 \%$ respectively, compared to control under a sandy soil and irrigation water affected by salts. The interaction between Sakha-1 cultivar, plant compost, and $1.5 \mathrm{~L} \mathrm{ha}^{-1}$ of biostimulants (VIUSID ${ }^{\circledR}$ agro) achieved the optimal combination, providing the highest grain yield, as compared to all other treatments. The combination of these treatments is recommended in order to improve faba bean productivity under similar conditions.

Keywords: VIUSID ${ }^{\circledR}$ agro compost, chicken manure, yield, storage protein

\section{Introduction}

Faba bean, or broad bean (Vicia faba L.), belongs to the Leguminosae family (Fabaceae) and is one of the most important legume crops cultivated in Egypt and worldwide. Faba bean seeds are known for their valuable source of protein, carbohydrates, and minerals (Broughton et al., 2003; Khalafallah et al., 2008; Dawood and El-Awadi, 2015).

Soil and water salinity, as well as other related problems, are a major challenge for global food production (Minhas et al., 2020). Soil salinization and saline water irrigation are major factors contributing to productivity loss of cultivated soils and have a harmful effect on soilwater-plant relations, hindering yield of crops (Plaut et al., 2013; Ouzounidou et al., 2014; Shrivastava and Kumar, 2015; De Pascale et al., 2017). Sandy soils are mostly exposed to a combination of abiotic stresses, namely low water availability, saline water, saline soil, and nutrient deficiency (Dawood et al., 2019).

The application of organic matter (OM) has shown to provide benefits to soil properties and plant growth. Prabu and Uthaya (2006) reported that organic manures play an important role in sustaining physical, chemical, and biological conditions of soil and facilitate the availability of macro and micronutrients to the plant rhizosphere. Organic compounds contribute to plant growth and development and encourage enzymatic or hormonal growth, as it contains nutrients needed by the plant (AL-Bayati and Kammel, 2014). In addition, Dhary and Al-Baldawi (2017) showed that the application of organic fertilizers significantly increases yield of faba bean seeds. However, Chaichi et al. (2018) indicated that vermicomposting tea is a useful fertilizer to improve growth in faba bean.

The application of biostimulants have the potential to improve crop resilience to environmental disturbances (Van Oosten et al., 2017). In soils with low fertility and lacking nutrients, the use of biostimulants could improve yield and quality of plants (Abdelgawad et al., 2018). In addition, biostimulants have been reported to confer benefits to several crops. For instance, foliar application of VIUSID ${ }^{\circledR}$ agro increased biomass production of beetroot, lettuce, chard, radish tomato, bean, maize, and tobacco plants (Peña et al., 2016; Peña et al., 2017; Atta et al., 2017; Peña et al., 2018). Moreover, Abbas (2013) found that biostimulants increase the protein contents in faba bean.

Abiotic stresses in sandy soils, such as saline water, saline soil, and lack of nutrients compromises yield faba bean. Therefore, we investigated the effects of organic amendments and the supply of biostimulant VIUSID $^{\circledR}$ agro on the response of faba bean cultivars by targeting key morphological characteristics, seed yield, and protein content under a sandy soil and irrigation affected by salt water.

\section{Materials and Methods}

\section{Experimental area}

Two field experiments were carried out during two successive winter seasons of 2016/2017 and 2017/2018 in Wadi El-Natroon, El-Beheira Governorate, Egypt $\left(30^{\circ} 32^{\prime} 30^{\prime \prime}\right.$ and $30^{\circ} 33^{\prime} 0^{\prime \prime} \mathrm{N}, 2^{\circ} 57^{\prime} 15^{\prime \prime}$, and $29^{\circ} 58^{\prime} 15^{\prime \prime} \mathrm{E}$, altitudes $31 \mathrm{~m}$ and $59 \mathrm{~m}$ ) under a drip irrigation system. 
Monthly mean temperature and relative humidity were recorded (Table 1). Monthly mean temperature values decreased gradually from 21.4 and $22.7^{\circ} \mathrm{C}$ in Nov to 15.4 and $13.9^{\circ} \mathrm{C}$ in Jan in $2016 / 2017$ and $2017 / 2018$ seasons, respectively. The maximum relative humidity was 62.3 and $60.3 \%$ during Feb and Jan in both years, respectively. The maximum amount of rainfall was 91.7 $\mathrm{mm}$ and $40.98 \mathrm{~mm}$ during Apr and Jan in both years, respectively.

Soil samples were collected and tested in the lab. The soil physical analysis was conducted according to Klute (1986) and the chemical analysis was performed according to Page et al. (1982). Soil and irrigation water properties are listed in Tables 2 and 3. The soil of the experimental site had a sandy texture, with salinity

Table 1 - Mean monthly climate data at experimental location in Wadi El-Natroon in 2016/2017 and 2017/2018 seasons* .

\begin{tabular}{lcccccc}
\hline & \multicolumn{3}{c}{$2016 / 2017$} & \multicolumn{3}{c}{$2017 / 2018$} \\
\cline { 2 - 7 } Month & Temperature & $\begin{array}{c}\text { Relative } \\
\text { humidity }\end{array}$ & Rainfall & Temperature & $\begin{array}{c}\text { Relative } \\
\text { humidity }\end{array}$ & Rainfall \\
\hline & ${ }^{\circ} \mathrm{C}$ & $\%$ & $\mathrm{~mm}$ & ${ }^{\circ} \mathrm{C}$ & $\%$ & $\mathrm{~mm}$ \\
Nov & 21.4 & 23.3 & 30.23 & 22.7 & 25.0 & 20.86 \\
Dec & 19.3 & 21.2 & 50.08 & 16.5 & 18.5 & 8.69 \\
Jan & 15.4 & 59.5 & 5.68 & 13.9 & 60.3 & 40.98 \\
Feb & 16.9 & 62.3 & 12.93 & 15.6 & 54.0 & 11.6 \\
Mar & 20.9 & 50.0 & 0.32 & 21.5 & 43.3 & 1.27 \\
Apr & 24.7 & 41.0 & 91.07 & 26.2 & 38.3 & 5.63 \\
\hline
\end{tabular}

*Data obtained from the Central Laboratory for Agricultural Climate (CLAC), Agricultural Research Center (ARC), Egypt.

Table 2 - Soil properties in the experimental site in 2016/2017 and 2017/2018 seasons.

\begin{tabular}{lcc}
\hline Soil analysis & $2016 / 2017$ & $2017 / 2018$ \\
\hline Physical properties & & \\
Sand (\%) & 94.15 & 92.27 \\
Silt (\%) & 4.35 & 5.20 \\
Clay (\%) & 1.50 & 2.53 \\
Texture & Sandy & Sandy \\
Chemical properties & & \\
$\mathrm{pH}_{(1: 1)}$ & 7.43 & 7.29 \\
$\mathrm{EC}_{(1: 1)}\left(\mathrm{dS} \mathrm{m}^{-1}\right)$ & 5.54 & 5.22 \\
Organic matter (\%) & 0.51 & 0.62 \\
Total $\mathrm{CaCO}_{3}(\%)$ & 3.74 & 5.91 \\
Available N $\left(\mathrm{mg} \mathrm{kg}^{-1}\right)$ & 6.4 & 8.9 \\
Available $\mathrm{P}\left(\mathrm{mg} \mathrm{kg}^{-1}\right)$ & 1.65 & 2.04 \\
Available $\mathrm{K}_{\left(\mathrm{mg} \mathrm{kg}^{-1}\right)}$ & 168 & 187 \\
Irrigation system & Drip irrigation & Drip irrigation \\
\hline
\end{tabular}

Table 3 - Chemical properties of irrigation water in the experimental site in 2016/2017 and 2017/2018 seasons.

\begin{tabular}{|c|c|c|c|c|c|c|c|c|c|}
\hline Season & $\mathrm{pH}$ & $\mathrm{EC}$ & & & Soluble & e ions (n & meq $\left.L^{-1}\right)$ & & \\
\hline & & $\mathrm{dS}^{-}$ & HCO3- & $\mathrm{Cl}-$ & SO4- & $\mathrm{Ca}++$ & $\mathrm{Mg}++$ & $\mathrm{Na}+$ & $\mathrm{K}+$ \\
\hline 2016 & 7.7 & 4.1 & 2.8 & 30.5 & 9.0 & 3.9 & 4.3 & 33.3 & 0.64 \\
\hline 2017 & 7.5 & 4.2 & 3.2 & 29.1 & 7.9 & 5.3 & 4.6 & 32.5 & 0.55 \\
\hline
\end{tabular}

(electrical conductivity - EC) 5.5 and $5.2 \mathrm{dS} \mathrm{m}^{-1}$ for both seasons, respectively, and was poor in macronutrients and micronutrients. The contents of $\mathrm{N}, \mathrm{P}$, and $\mathrm{K}$ available to plants were 6.4 and $8.9,1.6$ and 2.0, and 168 and $187 \mathrm{mg} \mathrm{kg}^{-1}$ in the first and second seasons, respectively. Moreover, the soil was poor in OM content 10.5 and $0.6 \%)$ in both seasons, respectively. Irrigation water was affected by salts. EC was $4.0 \mathrm{dS} \mathrm{m} \mathrm{m}^{-1}$ in the first and second seasons. The values of soil and irrigation water properties showed small differences of in both seasons of the present study.

\section{Experimental design and treatments}

This study comprised three Egyptian commercial cultivars of faba bean, namely Sakha-1, Sakha-4, and Giza-843, which were provided from the Agricultural Research Center (ARC), Giza, Egypt. Two organic amendments (plant compost and chicken manure) were applied. The plant compost was obtained from Quesna Agricultural Development Company, Egypt, while chicken manure was provided from Giza, Egypt. Both organic amendments were incorporated at the rates of $12 \mathrm{t} \mathrm{ha}^{-1}$ before sowing. Four foliar sprays of biostimulant (VIUSID $^{\circledR}$ agro provided from Catalysis, Spain) were applied at the rates $0.5,1.0$, and $1.5 \mathrm{~L} \mathrm{ha}^{-1}$. All concentrations of VIUSID ${ }^{\circledR}$ agro were applied in three equal intervals at 45, 60 and 75 days after sowing.

The study was conducted in a split-split-plot design in a randomized complete block design with four replications. The main plots were allotted to the two organic amendments. The four levels of biostimulants (VIUSID ${ }^{\circledR}$ agro) were assigned to sub-plots and the three cultivars were allocated to sub-sub-plots. Each sub-sub-plot consisted of 4 rows of $0.70 \mathrm{~m}$ of width and $5.0 \mathrm{~m}$ of length, that is, each experimental plot was 14 $\mathrm{m}^{2}$. Each main plot was surrounded by a wide ridge $(1.4 \mathrm{~m})$ to avoid interference of the four VIUSID ${ }^{\circledR}$ agro treatments. The composition of VIUSID ${ }^{\circledR}$ agro and two organic amendments are presented in Tables 4 and 5 , respectively.

\section{Cultural practices}

Sowing dates were 05 and 09 Nov in 2016/17 and $2017 / 18$, respectively seeds were planted at the rate of

Table 4 - Components \% of VIUSID ${ }^{\circledR}$ agro used in 2016/2017 and 2017/2018 seasons.

\begin{tabular}{lclc}
\hline Components & $\%$ & \multicolumn{1}{c}{ Components } & $\%$ \\
\hline Potassium phosphate & 5.00 & Calcium pantothenate & 0.115 \\
Malic acid & 4.60 & Pyridoxal & 0.225 \\
Glucosamine & 4.60 & Folic acid & 0.05 \\
Arginine & 4.15 & Cyanocobalamin & 0.0005 \\
Glycine & 2.35 & Monoammoniumglycyrrizinate & 0.23 \\
Ascorbic acid & 1.15 & Zinc sulphate & 0.115 \\
\hline All compounds were subjected to a molecular activation process, according \\
to Catalysis (2014).
\end{tabular}


Table 5 - Chemical and physical properties of organic amendments in 2016/2017 and 2017/2018 seasons.

\begin{tabular}{lcccc}
\hline \multirow{2}{*}{ Bulk Density $\left(\mathrm{kg} \mathrm{m}^{-3}\right)$} & \multicolumn{2}{c}{ Plant compost } & \multicolumn{2}{c}{ Chicken manure } \\
\cline { 2 - 5 } & $\begin{array}{c}1^{\text {st }} \\
\text { Season }\end{array}$ & $\begin{array}{c}2^{\text {nd }} \\
\text { Season }\end{array}$ & $\begin{array}{c}1^{\text {st }} \\
\text { Season }\end{array}$ & $\begin{array}{c}2^{\text {nd }} \\
\text { Season }\end{array}$ \\
\hline Moisture content (\%) & 25.00 & 24.00 & 22.00 & 23.00 \\
$\mathrm{pH}_{(1: 10)}$ & 7.00 & 7.1 & 8.04 & 8.00 \\
EC $_{(1: 10)}\left(\mathrm{dS} \mathrm{m}^{-1}\right)$ & 2.65 & 2.70 & 3.20 & 3.10 \\
Total Nitrogen (\%) $_{\text {Organic Matter (\%) }}$ & 2.15 & 2.20 & 2.24 & 2.26 \\
Organic Carbon (\%) & 1.671 & 1.686 & 1.885 & 1.870 \\
Ash (\%) & 38.90 & 38.85 & 17.98 & 17.95 \\
C: N Ratio & 32.8 & 32.8 & 69.00 & 69.25 \\
Total Phosphorus $\left(\mathrm{P}_{2} \mathrm{O}_{5}\right)(\%)$ & $18: 1$ & $17.6: 1$ & $8: 1$ & $7.9: 1$ \\
Total Potassium $(\%)$ & 1.09 & 1.07 & 0.16 & 0.15 \\
Weed seeds & 2.55 & 2.50 & 0.59 & 0.60 \\
Nematodes & - & - & - & - \\
\hline
\end{tabular}

$168 \mathrm{~kg} \mathrm{ha}^{-1}$ using dry planting by hand on the two sides of the ridge in hills with $30 \mathrm{~cm}$ spacing. Thinning was carried out at 30 days after sowing to leave two plants per hill. Calcium superphosphate fertilizer $\left(15.5 \% \mathrm{P}_{2} \mathrm{O}_{5}\right)$ at the rate of $60 \mathrm{~kg} \mathrm{P}_{2} \mathrm{O}_{5}$ ha $^{-1}$ was applied uniformly before sowing. Potassium sulphate $\left(48 \% \mathrm{~K}_{2} \mathrm{O}\right)$ was applied at the rate of $120 \mathrm{~kg} \mathrm{~K}_{2} \mathrm{O}$ ha $^{-1}$. The application of $\mathrm{K}$ fertilizer started at 30 days after sowing through eight equal doses at seven-day intervals. Weed management was carried out during the growing season by hoeing twice, before the $1^{\text {st }}$ and the $2^{\text {nd }}$ doses of biostimulants (VIUSID $^{\circledR}$ agro). The levels of VIUSID ${ }^{\circledR}$ agro were sprayed with a hand sprayer at 10h00-12h00 a.m. Cultural practices were conducted according to the recommendation of the Agricultural Research Center (ARC), Egyptian Ministry of Agriculture.

\section{Data collection}

We collected data on growth, yield, and their components by randomly selecting five plants from the two inner rows of each sub-sub plot at harvest time to record plant height $(\mathrm{cm})$, number of branches per plant, number of pods per plant, number of seeds per plant, yield per plant (g), and seed index (weight of 100 seed, in grams).

Biological yield $\left(t \mathrm{ha}^{-1}\right)$ was assessed by weighing the whole plant from each sub-sub plot after complete drying and converted to $\mathrm{tha}^{-1}$. Seed yield $\left(\mathrm{kg} \mathrm{ha}^{-1}\right)$ was assessed by weighing seeds produced from each sub-sub plot and converted to kg per hectare. The harvest index (HI) was calculated dividing seed yield by biological yield, according to the formula: HI $(\%)=($ seed yield $/$ biological yield) $\times 100$.

\section{Determination of total soluble and seed storage proteins}

The total soluble protein and seed protein contents were extracted and determined as reported by Larkindale and
Huang (2004). Leaves and seeds were weighed, $0.5 \mathrm{~g}$ and $0.2 \mathrm{~g}$, respectively, and then ground to a fine powder with liquid nitrogen. The amount of $500 \mathrm{uL}$ of phosphate buffer $\mathrm{pH}: 7$ was added to $0.5 \mathrm{~g}$ of frozen ground powder of leaf tissue, while $1.5 \mathrm{~mL}$ of the same buffer was added to $0.5 \mathrm{~g}$ of ground powder seed then homogenized in liquid nitrogen and then centrifuged at $4{ }^{\circ} \mathrm{C}$ for $15 \mathrm{~min}$ at $10000 \times \mathrm{g}$. The supernatant was used to determine protein concentration according to Bradford (1976) and with the help of crystalline bovine serum albumin as a standard curve.

\section{Poly acrylamide gel electrophoresis of proteins}

SDS PAGE was performed as described by Leammli et al. (1970).

\section{Statistical analysis}

The test for normal distribution of residuals was carried out according to the Shapiro and Wilk method (1965), using the SPSS Statistics (2008) software package. Data over two years were subjected to the combined analysis of variance (ANOVA), using the mixed effects model. Before conducting the ANOVA, homogeneity of error variances of two years was examined using the Bartlett's test (1937). Least Significant Differences (LSD) were calculated to detect the significant differences at $5 \%$ probability between the means according to Snedecor and Cochran (1989) by using the MSTAT-C software package (Freed et al., 1989).

\section{Results}

\section{Effect of cultivar, organic amendments, and VIUSID $^{\circledR}$ agro treatments on faba bean yield}

The results in Table 6 showed that Sakha-1 cultivar achieved the highest values of plant height $(62 \mathrm{~cm})$, number of branches per plant (2.4), number of pods per plant (10.1), number of seeds per plant (25.2), yield per plant $(23.7 \mathrm{~g})$, seed yield $\left(2.9 \mathrm{t} \mathrm{ha}^{-1}\right)$, biological yield (8.0-t ha-1), and harvest index (36.6\%). On the contrary, the lowest values of all studied traits of yield and its components expect seed index (93.7 g) were recorded for Giza-843 cultivar.

There was a significant difference between organic amendments in all growth and yield parameters, expect for biological yield. The results of Table 6 also revealed that the treatment with plant compost achieved the highest values of plant height $(60.6 \mathrm{~cm})$, number of branches per plant (2.4), number of pods per plant (9.8), number of seeds per plant (24.4), yield per plant $(22.8$ g), seed yield $\left(2.7-\mathrm{t} \mathrm{ha}^{-1}\right)$, biological yield $\left(7.6-\mathrm{t} \mathrm{ha}^{-1}\right)$, harvest index $(33.8 \%)$, and seed index (92.5 g) compared to chicken manure treatment.

The VIUSID ${ }^{\circledR}$ agro rates showed a significant increase in in all growth and yield parameters using a 
foliar application of VIUSID ${ }^{\circledR}$ agro, except for harvest index. Remarkably, the results in Table 6 clearly showed that spraying faba bean plants with $1.5 \mathrm{~L} \mathrm{ha}^{-1}$ of VIUSID ${ }^{\circledR}$ agro achieved the highest values of plant height 163.8 $\mathrm{cm})$, number of branches per plant (2.5), number of pods per plant (10.2), number of seeds per plant (26.0), yield per plant $(24.3 \mathrm{~g})$, seed yield $\left(2.8\right.$-t ha $\left.\mathrm{ha}^{-1}\right)$, biological yield (8.7-t ha $\left.{ }^{-1}\right)$, and seed index (93.5 g). However, regarding the harvest index, the highest value was recorded in the untreated plots $(37.5 \%)$.

A significant difference between cultivars and organic amendments in all growth and yield parameters was observed (Table 7). The response of Sakha-1 cultivar to plant compost triggered the highest response of a number of seeds per plant (26.4), yield per plant $(25.8$ g), seed yield (2.9-t ha- $\left.{ }^{-1}\right)$, biological yield (8.4-t ha-1), and harvest index $(33.4 \%)$ and there was a significant difference compared to other treatments. In addition, the same interaction (Sakha-1 cultivar and plant compost) achieved the highest values of plant height $(64.9 \mathrm{~cm})$, number of branches per plant (2.5), number of pods per plant (10.6), seed index (93.8 g), and there was no significant difference compared to other treatments.

All application rates of VIUSID ${ }^{\circledR}$ agro significantly affected the studied traits of faba bean plant (Table 8). Generally, spraying the faba bean plants with $1.5 \mathrm{~L} \mathrm{ha}^{-1}$ of VIUSID ${ }^{\circledR}$ agro significantly increased grain yield. In plots with the foliar application of VIUSID ${ }^{\circledR}$ agro at the rate of $1.5 \mathrm{~L} \mathrm{ha}^{-1}$, seed yield of the cultivars, Sakha-4, Sakha-1, and Giza-843 was increased by $17.2,33.0$, and $19.8 \%$ respectively, compared to untreated plots. Table 8 showed that spraying Sakha-1 plants with $1.5 \mathrm{~L} \mathrm{ha}^{-1}$ of VIUSID ${ }^{\circledR}$ agro resulted in the highest values of plant height $(68.0 \mathrm{~cm})$, number of branches per plant $(2.7)$, number of pods per plant (11.2), number of seeds per plant (28.5), yield per plant $(27.2 \mathrm{~g})$, seed yield (3.3-t $\left.\mathrm{ha}^{-1}\right)$, biological yield $\left(9.5-\mathrm{tha}^{-1}\right)$, and seed index (95.4 g) in comparison to the other treatments. In contrast, the greatest value of harvest index (39.3\%) was recorded for Sakha-4 cultivar in untreated plots.

Table 6 - Mean performance of yield components and yield for cultivars, organic amendments, and VIUSID $®$ agro (data are combined across 2016/2017 and 2017/2018 seasons).

\begin{tabular}{|c|c|c|c|c|c|c|c|c|c|}
\hline Factors & Seed Yield & $\begin{array}{l}\text { Biological } \\
\text { Yield }\end{array}$ & $\begin{array}{l}\text { Harvest } \\
\text { Index }\end{array}$ & $\begin{array}{l}\text { Plant } \\
\text { Height }\end{array}$ & $\begin{array}{l}\text { No. of branches } \\
\text { per plant }\end{array}$ & $\begin{array}{l}\text { No. of pods } \\
\text { per plant }\end{array}$ & $\begin{array}{l}\text { No. of seeds } \\
\text { per plant }\end{array}$ & Yield per plant & $\begin{array}{l}\text { Seed } \\
\text { Index }\end{array}$ \\
\hline & \multicolumn{2}{|c|}{$\longrightarrow$ tha $^{-1}$} & $\%$ & $\mathrm{~cm}$ & & & & $-\mathrm{g}$ & 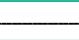 \\
\hline Sakha-4 & 2.55 & 7.22 & 35.90 & 54.70 & 2.38 & 9.26 & 23.41 & 19.85 & 87.13 \\
\hline Sakha-1 & 2.91 & 8.08 & 36.64 & 62.00 & 2.45 & 10.14 & 25.28 & 23.78 & 92.01 \\
\hline Giza-843 & 2.38 & 7.36 & 32.94 & 57.75 & 2.27 & 8.51 & 21.78 & 20.84 & 93.74 \\
\hline $\mathrm{LSD}_{0.05}$ & 0.06 & 0.32 & 1.66 & 1.26 & ns & 0.24 & 0.33 & 0.13 & 1.33 \\
\hline Chicken Manure & 2.53 & 7.46 & 34.47 & 55.68 & 2.29 & 8.74 & 22.54 & 20.13 & 89.37 \\
\hline Plant Compost & 2.70 & 7.65 & 35.85 & 60.62 & 2.44 & 9.87 & 24.44 & 22.85 & 92.55 \\
\hline $\mathrm{LSD}_{0.05}$ & sig. & ns & sig. & sig. & sig. & sig. & sig. & sig. & sig. \\
\hline Control & 2.34 & 6.30 & 37.54 & 51.70 & 2.14 & 8.26 & 20.92 & 18.49 & 87.80 \\
\hline $0.5 \mathrm{~L} \mathrm{ha}^{-1}$ & 2.55 & 7.26 & 35.48 & 57.08 & 2.29 & 8.96 & 22.74 & 20.68 & 90.33 \\
\hline $1.0 \mathrm{~L} \mathrm{ha}^{-1}$ & 2.69 & 7.89 & 34.36 & 60.00 & 2.50 & 9.80 & 24.25 & 22.40 & 92.13 \\
\hline $1.5 \mathrm{~L} \mathrm{ha}^{-1}$ & 2.89 & 8.77 & 33.26 & 63.81 & 2.53 & 10.21 & 26.05 & 24.38 & 93.58 \\
\hline $\mathrm{LSD}_{0.05}$ & 0.03 & 0.28 & 1.59 & 1.19 & 0.14 & 0.27 & 0.29 & 0.28 & 1.42 \\
\hline
\end{tabular}

sig = significant; $\mathrm{ns}=$ not significant.

Table 7 - Mean performance of yield components and yield for cultivars and organic amendments interaction (data are combined across 2016/2017 and 2017/2018 seasons).

\begin{tabular}{|c|c|c|c|c|c|c|c|c|c|c|}
\hline Cultivars & $\begin{array}{c}\text { Organic } \\
\text { Amendments }\end{array}$ & $\begin{array}{l}\text { Seed } \\
\text { Yield }\end{array}$ & $\begin{array}{l}\text { Biological } \\
\text { Yield }\end{array}$ & $\begin{array}{l}\text { Harvest } \\
\text { Index }\end{array}$ & $\begin{array}{l}\text { Plant } \\
\text { Height }\end{array}$ & $\begin{array}{l}\text { No. of branches } \\
\text { per plant }\end{array}$ & $\begin{array}{l}\text { No. of pods } \\
\text { per plant }\end{array}$ & $\begin{array}{l}\text { No. of seeds } \\
\text { per plant }\end{array}$ & $\begin{array}{l}\text { Yield per } \\
\text { plant }\end{array}$ & $\begin{array}{l}\text { Seed } \\
\text { Index }\end{array}$ \\
\hline & & - & $a^{-1}$ & $\%$ & $\mathrm{~cm}$ & & & & 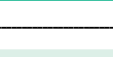 & 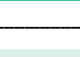 \\
\hline \multirow{2}{*}{ Sakha-4 } & Chicken manure & 2.47 & 7.28 & 34.37 & 52.33 & 2.36 & 8.66 & 22.51 & 18.59 & 85.01 \\
\hline & Plant compost & 2.64 & 7.16 & 37.43 & 57.07 & 2.41 & 9.87 & 24.31 & 21.10 & 89.26 \\
\hline \multirow{2}{*}{ Sakha-1 } & Chicken manure & 2.87 & 7.70 & 37.83 & 59.01 & 2.34 & 9.63 & 24.08 & 21.75 & 90.17 \\
\hline & Plant compost & 2.96 & 8.47 & 35.45 & 64.98 & 2.56 & 10.65 & 26.49 & 25.81 & 93.85 \\
\hline \multirow{2}{*}{ Giza-843 } & Chicken manure & 2.26 & 7.39 & 31.21 & 55.70 & 2.18 & 7.94 & 21.05 & 20.05 & 92.93 \\
\hline & Plant compost & 2.50 & 7.32 & 34.68 & 59.80 & 2.35 & 9.08 & 22.51 & 21.63 & 94.56 \\
\hline $\mathrm{LSD}_{0.05}$ & & 0.07 & 0.34 & 1.88 & ns & ns & ns & 0.43 & 0.52 & ns \\
\hline
\end{tabular}

$\mathrm{ns}=$ non-significant. 
The results indicated a significant difference between organic amendments and VIUSID ${ }^{\circledR}$ agro interactions in all growth and yield parameters traits, except for the number of branches per plant (Table 9). Interestingly, the results of Table 9 show that the interaction between plant compost and $1.5 \mathrm{~L} \mathrm{ha}^{-1}$ of VIUSID $^{\circledR}$ agro resulted in the greatest values of plant height $(67.2 \mathrm{~cm})$, number of branches per plant $(2.5)$, number of pods per plant (11.0), number of seeds per plant (27.7), yield per plant $(26.3 \mathrm{~g})$, seed yield (3.0-t $\mathrm{ha}^{-1}$ ), biological yield (9.0-t ha $\left.{ }^{-1}\right)$, and seed index (95.4 g). However, the incorporation of chicken manure to untreated plots resulted in the greatest values of harvest index (36.9\%).

Foliar application of VIUSID ${ }^{\circledR}$ agro and organic amendments improved the performance of all faba bean cultivars under sandy soil conditions affected by salts and irrigation with salt-affected irrigation water (Table 10). Our results clearly showed that the interaction between three factors studied (organic amendments, VIUSID $^{\circledR}$ agro and cultivars) significantly affects plant yield traits, but it did not influence plant height, number of branches per plant, biological yield, and harvest index. The results in Table 10 show that the interaction between Sakha-1cultivar, plant compost, and $1.5 \mathrm{~L} \mathrm{ha}^{-1}$ of VIUSID ${ }^{\circledR}$ agro rates achieved the highest response on plant height $(72.7 \mathrm{~cm})$, number of branches per plant (2.7), number of pods per plant (11.9), number of seeds per plant (31.2), yield per plant (30.3 g), seed yield (3.5-t $\mathrm{ha}^{-1}$ ) and biological yield (10.3-t ha-1). Remarkably, the highest value of harvest index $(40.3 \%)$ was recorded for Sakha-4 cultivar in plots where plant compost was incorporated and VIUSID ${ }^{\circledR}$ agro was not applied. However, the greatest value of seed index (95.4 g) was recorded for Giza-843 cultivar in plots where plant compost was incorporated and VIUSID ${ }^{\circledR}$ agro was applied at the rate of $1.5 \mathrm{~L} \mathrm{ha}^{-1}$.

\section{Effect of organic amendments and VIUSID ${ }^{\circledR}$ agro concentrations on protein content of faba bean}

We performed protein profiling via ID protein gel electrophoresis to trace the changes in protein pattern in response to salinity conditions of soil and irrigation

Table 8 - Mean performance of yield components and yield for cultivars and VIUSID ${ }^{\circledR}$ agro interaction (data are combined across $2016 / 2017$ and $2017 / 2018$ seasons).

\begin{tabular}{|c|c|c|c|c|c|c|c|c|c|c|}
\hline Cultivars & $\begin{array}{l}\text { VIUSID }^{\circledast} \\
\text { agro }\end{array}$ & $\begin{array}{l}\text { Seed } \\
\text { Yield }\end{array}$ & $\begin{array}{l}\text { Biological } \\
\text { Yield }\end{array}$ & $\begin{array}{l}\text { Harvest } \\
\text { Index }\end{array}$ & $\begin{array}{l}\text { Plant } \\
\text { Height }\end{array}$ & $\begin{array}{l}\text { No. of branches } \\
\text { per plant }\end{array}$ & $\begin{array}{l}\text { No. of pods } \\
\text { per plant }\end{array}$ & $\begin{array}{l}\text { No. of seeds } \\
\text { per plant }\end{array}$ & $\begin{array}{c}\text { Yield } \\
\text { per plant }\end{array}$ & $\begin{array}{l}\text { Seed } \\
\text { Index }\end{array}$ \\
\hline \multirow{5}{*}{ Sakha-4 } & $\mathrm{L} \mathrm{ha}^{-1}$ & 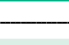 & ${ }^{-1}$ & $\%$ & $\mathrm{~cm}$ & & & & & 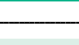 \\
\hline & Control & 2.35 & 6.01 & 39.30 & 49.69 & 2.16 & 8.08 & 21.25 & 17.42 & 85.47 \\
\hline & 0.5 & 2.48 & 6.98 & 36.13 & 53.96 & 2.33 & 9.14 & 22.23 & 18.75 & 86.61 \\
\hline & 1.0 & 2.62 & 7.62 & 34.60 & 56.20 & 2.54 & 9.94 & 24.15 & 21.06 & 87.74 \\
\hline & 1.5 & 2.77 & 8.29 & 33.58 & 58.94 & 2.49 & 9.91 & 25.99 & 22.15 & 88.71 \\
\hline \multirow{4}{*}{ Sakha-1 } & Control & 2.58 & 6.92 & 37.77 & 54.64 & 2.16 & 8.98 & 22.04 & 19.88 & 87.01 \\
\hline & 0.5 & 2.78 & 7.64 & 36.77 & 60.74 & 2.38 & 9.72 & 24.55 & 23.47 & 92.04 \\
\hline & 1.0 & 2.95 & 8.23 & 36.23 & 64.51 & 2.56 & 10.63 & 25.99 & 24.48 & 93.57 \\
\hline & 1.5 & 3.35 & 9.54 & 35.77 & 68.09 & 2.73 & 11.24 & 28.56 & 27.28 & 95.42 \\
\hline \multirow{4}{*}{ Giza-843 } & Control & 2.09 & 5.97 & 35.55 & 50.76 & 2.12 & 7.71 & 19.47 & 18.17 & 90.93 \\
\hline & 0.5 & 2.38 & 7.15 & 33.55 & 56.55 & 2.18 & 8.02 & 21.44 & 19.82 & 92.35 \\
\hline & 1.0 & 2.50 & 7.82 & 32.25 & 59.28 & 2.40 & 8.83 & 22.60 & 21.66 & 95.08 \\
\hline & 1.5 & 2.56 & 8.48 & 30.42 & 64.41 & 2.37 & 9.48 & 23.61 & 23.71 & 96.62 \\
\hline $\mathrm{LSD}_{0.05}$ & & 0.05 & 0.49 & 2.77 & 2.07 & 0.24 & 0.47 & 0.52 & 0.49 & 2.27 \\
\hline
\end{tabular}

Table 9 - Mean performance of yield components and yield for organic amendments and VIUSID® agro interaction (data are combined acrosS 2016/2017 and 2017/2018 seasons).

\begin{tabular}{|c|c|c|c|c|c|c|c|c|c|c|}
\hline $\begin{array}{l}\text { Organic } \\
\text { Amendments }\end{array}$ & $\begin{array}{l}\text { VIUSID }^{\circledR} \\
\text { agro }\end{array}$ & $\begin{array}{l}\text { Seed } \\
\text { Yield }\end{array}$ & $\begin{array}{l}\text { Biological } \\
\text { Yield }\end{array}$ & $\begin{array}{l}\text { Harvest } \\
\text { Index }\end{array}$ & $\begin{array}{l}\text { Plant } \\
\text { Height }\end{array}$ & $\begin{array}{l}\text { No. of branches } \\
\text { per plant }\end{array}$ & $\begin{array}{l}\text { No. of pods } \\
\text { per plant }\end{array}$ & $\begin{array}{l}\text { No. of seeds } \\
\text { per plant }\end{array}$ & $\begin{array}{l}\text { Yield per } \\
\text { plant }\end{array}$ & $\begin{array}{l}\text { Seed } \\
\text { Index }\end{array}$ \\
\hline & $\mathrm{L} \mathrm{ha}^{-1}$ & 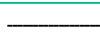 & $a^{-1}$ & $\%$ & $\mathrm{~cm}$ & & & & 2 & 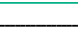 \\
\hline \multirow[t]{4}{*}{ Chicken manure } & Control & 2.26 & 6.19 & 36.94 & 50.41 & 2.09 & 7.53 & 20.53 & 17.75 & 86.82 \\
\hline & 0.5 & 2.48 & 7.27 & 34.56 & 54.74 & 2.23 & 8.66 & 21.99 & 19.40 & 88.59 \\
\hline & 1.0 & 2.61 & 7.82 & 33.61 & 57.24 & 2.38 & 9.36 & 23.25 & 20.95 & 89.97 \\
\hline & 1.5 & 2.78 & 8.55 & 32.77 & 60.34 & 2.48 & 9.42 & 24.40 & 22.43 & 92.10 \\
\hline \multirow{3}{*}{ Plant compost } & 0.5 & 2.61 & 7.24 & 36.41 & 59.43 & 2.36 & 9.25 & 23.49 & 21.96 & 92.08 \\
\hline & 1.0 & 2.76 & 7.97 & 35.11 & 62.75 & 2.62 & 10.23 & 25.24 & 23.85 & 94.29 \\
\hline & 1.5 & 3.00 & 9.00 & 33.75 & 67.29 & 2.58 & 11.00 & 27.70 & 26.34 & 95.06 \\
\hline $\mathrm{LSD}_{0.05}$ & & 0.04 & 0.41 & 2.26 & 1.68 & ns & 0.38 & 0.42 & 0.40 & 2.01 \\
\hline
\end{tabular}


water and treatments alleviating these conditions. To this end, the total soluble protein in faba bean cultivars was determined and adjusted at 80 ug for sample. The soluble protein bands had the highest accumulation under sandy soil conditions and salt-affected irrigation water (Figure 1). Moreover, the protein profile showed that several protein bands were affected distinctly by organic amendments and VIUSID ${ }^{\circledR}$ agro compared to the control (Figure 1).

In the first gel, Sakha-4 cultivar showed a similar response to plant compost compared to the control. On the other hand, the total protein sample treated with chicken manure showed high accumulation, especially in Sakha-4 cultivar. Notably, protein band $\approx 150 \mathrm{KDa}$ was present only in the control, while protein band $\approx 110$ $\mathrm{KDa}$ existed in the treatment $0.5 \mathrm{~L} \mathrm{ha}^{-1}$ and $1.5 \mathrm{~L} \mathrm{ha}^{-1}$ of VIUSID ${ }^{\circledR}$ agro in combination with plant compost or chicken manure. Protein band $\approx 27 \mathrm{KDa}$ was absent in the treatment $1.5 \mathrm{~L} \mathrm{ha}^{-1}$ of VIUSID ${ }^{\circledR}$ agro in combination with chicken manure. Furthermore, there were two protein bands 67 and $\approx 25 \mathrm{KDa}$ that existed in all samples except for the control sample.

Table 10 - Mean performance of yield components and yield for cultivars, organic amendments and VIUSID® agro interaction (data are combined across 2016/2017 and 2017/2018 season).

\begin{tabular}{|c|c|c|c|c|c|c|c|c|c|c|c|}
\hline Cultivars & $\begin{array}{c}\text { Organic } \\
\text { Amendments }\end{array}$ & $\begin{array}{l}\text { VIUSID }^{\circledR} \\
\text { agro }\end{array}$ & $\begin{array}{l}\text { Seed } \\
\text { Yield }\end{array}$ & $\begin{array}{l}\text { Biological } \\
\text { Yield }\end{array}$ & $\begin{array}{l}\text { Harvest } \\
\text { Index }\end{array}$ & $\begin{array}{l}\text { Plant } \\
\text { Height }\end{array}$ & $\begin{array}{l}\text { No. of branches } \\
\text { per plant }\end{array}$ & $\begin{array}{c}\text { No. of pods } \\
\text { per plant }\end{array}$ & $\begin{array}{l}\text { No. of seeds } \\
\text { per plant }\end{array}$ & $\begin{array}{l}\text { Yield per } \\
\text { plant }\end{array}$ & $\begin{array}{l}\text { Seed } \\
\text { Index }\end{array}$ \\
\hline \multirow{9}{*}{ Sakha-4 } & & $\mathrm{L} \mathrm{ha}^{-1}$ & $-\mathrm{t}$ & $a^{-1}$ & $\%$ & $\mathrm{~cm}$ & & & & $\longrightarrow$ & 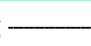 \\
\hline & \multirow{4}{*}{ Chicken manure } & Control & 2.27 & 5.97 & 38.22 & 49.11 & 2.09 & 7.41 & 20.64 & 16.86 & 84.53 \\
\hline & & 0.5 & 2.39 & 7.24 & 33.38 & 51.04 & 2.35 & 8.98 & 21.71 & 17.88 & 84.04 \\
\hline & & 1.0 & 2.54 & 7.69 & 33.12 & 52.58 & 2.54 & 9.59 & 23.08 & 19.45 & 85.00 \\
\hline & & 1.5 & 2.69 & 8.23 & 32.76 & 56.59 & 2.45 & 8.65 & 24.60 & 20.18 & 86.46 \\
\hline & \multirow{4}{*}{ Plant compost } & Control & 2.43 & 6.05 & 40.38 & 50.27 & 2.23 & 8.74 & 21.86 & 17.97 & 86.41 \\
\hline & & 0.5 & 2.56 & 6.71 & 38.89 & 56.88 & 2.31 & 9.30 & 22.75 & 19.63 & 89.18 \\
\hline & & 1.0 & 2.70 & 7.55 & 36.07 & 59.83 & 2.55 & 10.29 & 25.23 & 22.67 & 90.47 \\
\hline & & 1.5 & 2.85 & 8.35 & 34.39 & 61.28 & 2.54 & 11.16 & 27.38 & 24.13 & 90.96 \\
\hline \multirow{8}{*}{ Sakha-1 } & \multirow{4}{*}{ Chicken manure } & Control & 2.54 & 6.68 & 38.78 & 52.90 & 2.08 & 8.55 & 22.01 & 19.13 & 86.03 \\
\hline & & 0.5 & 2.79 & 7.51 & 37.86 & 58.13 & 2.19 & 9.23 & 23.56 & 21.33 & 89.38 \\
\hline & & 1.0 & 2.93 & 7.84 & 37.59 & 61.58 & 2.41 & 10.16 & 24.89 & 22.28 & 91.40 \\
\hline & & 1.5 & 3.21 & 8.75 & 37.07 & 63.45 & 2.70 & 10.59 & 25.84 & 24.26 & 93.89 \\
\hline & \multirow{4}{*}{ Plant compost } & Control & 2.63 & 7.17 & 36.77 & 56.38 & 2.24 & 9.41 & 22.06 & 20.63 & 87.98 \\
\hline & & 0.5 & 2.77 & 7.76 & 35.68 & 63.34 & 2.56 & 10.21 & 25.54 & 25.62 & 94.70 \\
\hline & & 1.0 & 2.96 & 8.63 & 34.87 & 67.44 & 2.70 & 11.09 & 27.09 & 26.68 & 95.74 \\
\hline & & 1.5 & 3.50 & 10.33 & 34.47 & 72.74 & 2.75 & 11.90 & 31.29 & 30.31 & 96.96 \\
\hline \multirow{8}{*}{ Giza-843 } & \multirow{4}{*}{ Chicken manure } & Control & 1.97 & 5.93 & 33.84 & 49.22 & 2.10 & 6.63 & 18.94 & 17.25 & 89.91 \\
\hline & & 0.5 & 2.27 & 7.07 & 32.44 & 55.03 & 2.14 & 7.79 & 20.69 & 19.00 & 92.33 \\
\hline & & 1.0 & 2.37 & 7.92 & 30.11 & 57.57 & 2.20 & 8.34 & 21.80 & 21.12 & 93.51 \\
\hline & & 1.5 & 2.45 & 8.66 & 28.47 & 60.97 & 2.29 & 9.03 & 22.78 & 22.85 & 95.96 \\
\hline & \multirow{4}{*}{ Plant compost } & Control & 2.22 & 6.02 & 37.27 & 52.30 & 2.14 & 8.80 & 20.00 & 19.10 & 91.96 \\
\hline & & 0.5 & 2.49 & 7.24 & 34.66 & 58.07 & 2.21 & 8.25 & 22.19 & 20.64 & 92.37 \\
\hline & & 1.0 & 2.63 & 7.72 & 34.40 & 60.99 & 2.60 & 9.33 & 23.40 & 22.21 & 96.65 \\
\hline & & 1.5 & 2.66 & 8.31 & 32.37 & 67.84 & 2.45 & 9.93 & 24.44 & 24.58 & 97.28 \\
\hline $\mathrm{LSD}_{0.05}$ & & & 0.21 & ns & ns & Is & ns & 0.66 & 0.73 & 0.69 & 3.49 \\
\hline
\end{tabular}

ns $=$ not significant.
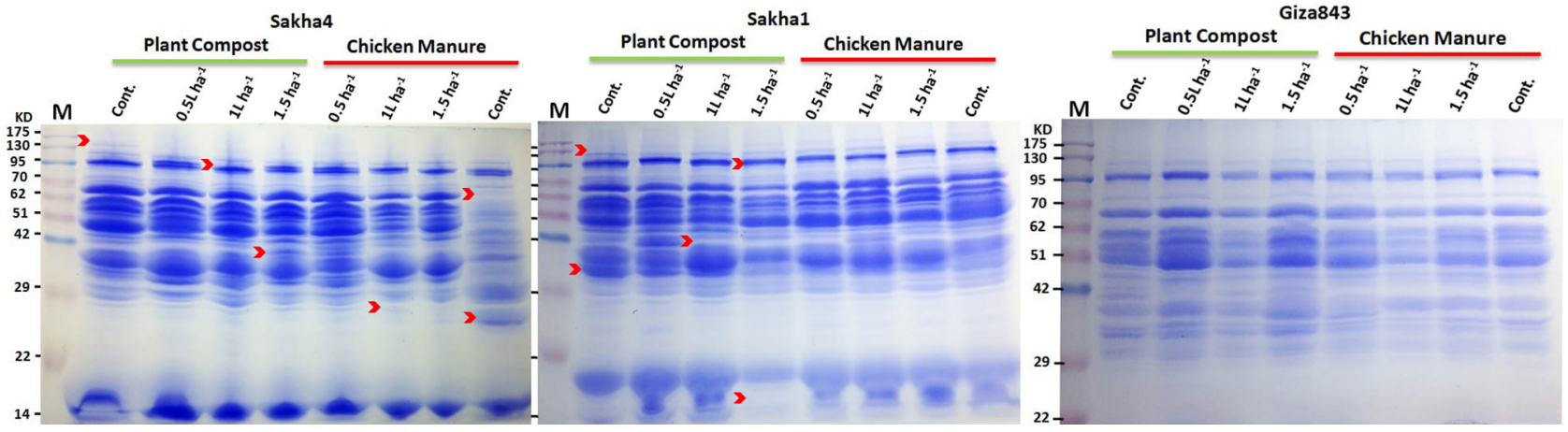

Figure 1 - SDS-PAGE profile of total soluble protein extracted from leaves of three faba bean cultivars. 
The protein content of Sakha-1 cultivar showed a similar response to Sakha-4; however, the plant compost showed a better response to salinity conditions than chicken manure. Protein band $42 \approx \mathrm{KDa}$ was expressed under the treatments $0.5 \mathrm{~L} \mathrm{ha}^{-1}$ and $1 \mathrm{~L} \mathrm{ha}^{-1}$ of VIUSID ${ }^{\circledR}$ agro in combination with plant compost. In general, density of protein bands for plant compost treatments was higher than the chicken manure treatments in Sakha-1 cultivar. Cultivar Giza-843 showed less protein accumulation than Sakha-1 and Sakha-4. Besides, it did not show any difference between protein bands in comparison to the vegetative protein bands profile of two other cultivars. Protein electrophoresis profiles showed no difference between cultivars or treatments compared to the control, whether in seed storage protein (Figure 1) or in soluble proteins of leaves (Figure 2). This indicates that these faba bean cultivars were not affected by the salinity condition of soil and irrigation water.

The ID protein gel electrophoresis results for seed storage protein of the three faba bean cultivars showed that the seed protein content was stable and not affected by soil salinity (Figures 1 and 2). Sakha-4 cultivar seed storage protein levels were increased when VIUSID ${ }^{\circledR}$ agro was applied at the concentration of $1.5 \mathrm{~L} \mathrm{ha}^{-1}$ in combination with chicken manure. Interestingly, in Sakha-4, the treatment VIUSID ${ }^{\circledR}$ agro at the concentration $0.5 \mathrm{~L} \mathrm{ha}^{-1}$ in combination with chicken manure showed the most efficacy to increase the total protein expressions (Figures 1 and 2). In Sakha-1 cultivar, storage protein response to plant compost and chicken manure treatments and showed high accumulation in combination with VIUSID ${ }^{\circledR}$ agro treatments (Figure 2). Finally, cultivar Giza-834 showed differences in protein bands of the seed storage protein due to different treatments, but it showed no differences comparing to the control sample in leave soluble proteins, especially under chicken manure treatments. All three cultivars showed differences in their protein profiles of leave soluble proteins, especially under plant compost treatment more than in the chicken manure treatment and few differences were observed in both organic amendments when testing their seed storage protein bands (Figures 1 and 2).

\section{Discussion}

The results of the present study show that all three faba bean cultivars (Sakha-1, Sakha-4, and Giza-834) expressed remarkable variation in response to soil salinization and salt-affected irrigation water, organic amendments, and VIUSID ${ }^{\circledR}$ agro as well as their combinations. Reductions in growth performance were observed in faba bean under saline conditions (Azooz, 2009). Metwali et al. (2015) concluded that salinity caused a significant decrease in all of faba bean growth traits, possibly attributed to inhibited growth and metabolism of legumes, affecting the activity of symbiotic bacteria in roots and limiting nitrogen fixation /Gaballah and Gomaa, 2005; Munns and Tester, 2008; Dulormne et al., 2010). In agreement with our findings, Radi et al. (2013) reported that Sakha-1 cultivar succeed in growing and production under salinity conditions.

The results of the present study showed that plant compost increased significantly all the traits studied, except for biological yield, compared to chicken manure in all cultivars grown under sandy soil conditions and salt-affected irrigation water. Analysis of both organic amendments used in the present study revealed that the high content of macronutrients $(\mathrm{N}, \mathrm{P}$, and $\mathrm{K})$ and organic matter (Table 5). Our results are in line with the positive role of plant compost on soil properties as it can release $\mathrm{N}, \mathrm{P}$, and $\mathrm{K}$ to the plant rhizosphere. The use of compost or other organic fertilizers determines the release of macro and micronutrients, improving the soil physical properties and faba bean growth and yield (Abdelhamid et al., 2004; Cucci et al., 2019). Gomaa et al. (2002) reported positive effects of using certain bioorganic applications on growth and yield of Vicia sativa. In this context, Fekadu et al. (2019) and Elnesairi and Elssalem (2020) indicated that the use of organic and inorganic amendments improves faba bean growth. On the other hand, Mahmoud et al. (2004) observed that the use of organic manures at rates 4.8-7.1-t ha ${ }^{-1}$ enhanced faba bean growth. Furthermore, Rady et al. (2016) showed that the organo-mineral fertilizer at a rate of $20-\mathrm{tha}^{-1}$ improved soil properties and growth and yield of Phaseolus vulgaris plants under salt stress. Gopinath et al. (2011) revealed a significant increase in

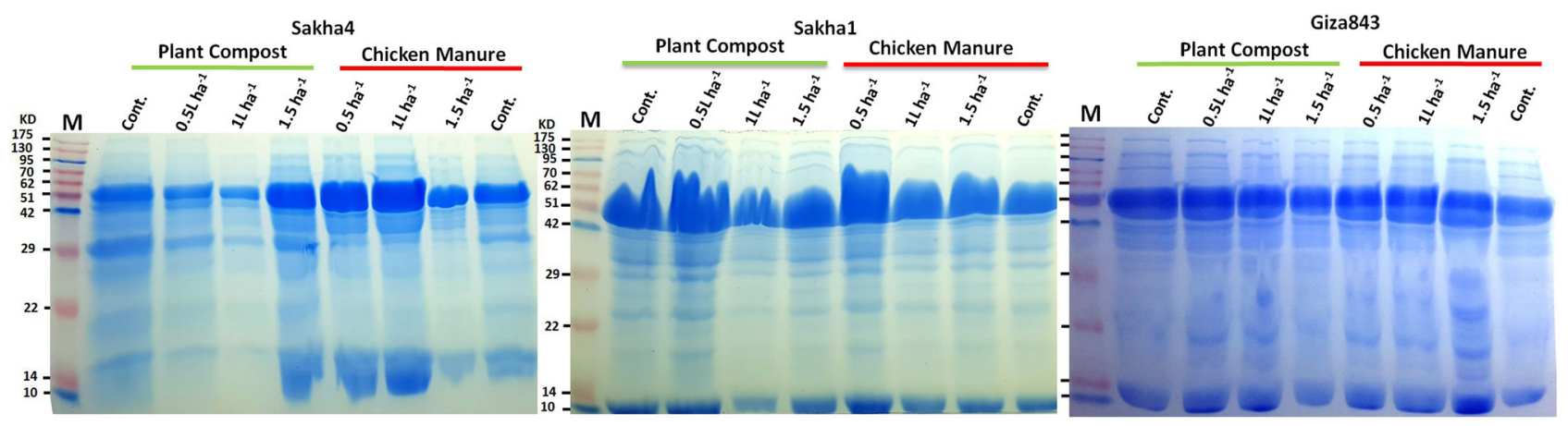

Figure 2 - SDS-PAGE profile of seed storage protein extracted from seeds of three faba bean cultivars. 
growth and yield of faba bean with the organic input. Similarly, El-Galad et al. (2013) concluded that the use of humic acid combined with compost and sulfur to give an economical grain yield of faba bean under salinity conditions. Compost at a rate of $15 \mathrm{t}$ feddan ${ }^{-1}$ with cobalt significantly increased the growth parameters of faba bean (Gad et al., 2017).

The incorporation of plant composts as organic amendment and $1.5 \mathrm{~L} \mathrm{ha}^{-1}$ VIUSID ${ }^{\circledR}$ agro as foliar application increased grain yield of all cultivars. This may be attributed to the potential effects of biostimulants in this treatment, for instance, increased absorption of soil nutrients provided by organic amendments thereby increasing faba bean yield. In this respect, biostimulants have been reported to stimulate plant growth by increasing plant metabolism, enhancing photosynthesis, and increasing absorption of soil nutrients (Yakhin et al., 2017). Moreover, biostimulants allow to improve water and nutrient use efficiency of crops, stimulate plant development, and counteract biotic stress (Bulgari et al., 2015; Van Oosten et al., 2017; Yakhin et al., 2017 and Caradonia et al., 2019). Furthermore, VIUSID ${ }^{\circledR}$ agro is a known growth enhancer, as this product has a positive influence on crop growth and yield (Catalysis, 2014). VIUSID $^{\circledR}$ agro contains many compounds that can enhance crop tolerance to salt stress. The amino acids of these compounds, which are considered the precursors and components of proteins, are important for cell growth and keep $\mathrm{pH}$ values favorable within plant cells. Amino acids are biostimulants that benefit plant growth and yield and significantly reduce injuries caused by salt stress (Rai, 2002). This may explain why VIUSID ${ }^{\circledR}$ agro showed better plant productivity response as compared to control.

Plant productivity is regulated on different molecular levels, in which the abundance of central proteins plays an important role. Plant protein expression levels are extremely affected under salt stress conditions. There is evidence that salinity induces the expression of salt-stress specific proteins (Ben-Hayyim et al., 1989) causing either a decrease in the level of total soluble proteins or an increase in some other polypeptides (Riccardi et al., 1998). Here, we showed that that soil salinization and salt-affected irrigation water induced changes in protein patterns in seeds and leaves of faba bean cultivars. In general, our data are agreement with Chao et al. (1999), who reported that the protein content increased in tomato plant under salt stress conditions. Furthermore, Sibole et al. (2003) observed that in clover plant, salinity increased the soluble protein content in the seedlings. Despite the results that indicate an enhancing effect for salt stress on protein content, other studies present contrasting results, indicating a negative effect for salt stress (Chen et al., 2007 and Cheruth et al., 2008). However, Abdelraouf et al. (2016) found that salt stress caused the misregulation of specific protein bands in faba bean. We observed that plant compost and VIUSID $^{\circledR}$ agro treatments enhanced the expression level in most protein bands. The plant compost generally showed a better effect on the total soluble protein in leaf tissue and in seed storage protein, which could explain the positive effect on faba bean growth and on protein expression specifically.

\section{Conclusion}

The incorporation of plant compost as an organic amendment and biostimulants (VIUSID ${ }^{\circledR}$ agro) through foliar application showed a superior effect on increasing faba bean components of yield and grain yield grown under sandy soil and salt-affected irrigation water. Moreover, our study revealed that several responsive proteins were affected and under the use of organic amendment and biostimulants (VIUSID ${ }^{\circledR}$ agro). The great level of accumulation regarding protein bands was not affected by all cultivars. Sakha-1 cultivar showed a better growth behavior when plant compost was incorporated into the soil compared to chicken manure. Similar findings were observed regarding the intensity of protein bands. The interaction between Sakha-1 cultivar, plant compost, and $1.5 \mathrm{~L} \mathrm{ha}^{-1}$ of biostimulants (VIUSID $^{\circledR}$ agro) achieved the optimal combination, leading to the highest grain yield as compared to all other treatments.

\section{Author's Contributions}

Conceptualization: Abbas, M.S. Data acquisition: Abdel-Lattif, H.M. Design of methodology: Elbadawy, R.A.; El-Shabrawi, H.M. Writing and editing: Abbas, M.S.

\section{References}

Abbas, S.M. 2013. The influence of biostimulants on the growth and on the biochemical composition of Vicia faba CV. Giza 3 beans. Romanian Biotechnological Letters 18: 8061-8068.

Abdelgawad, K.F.; Mhmoud, A.M.; Mohamed, H.F.Y. 2018. Foliar spraying with some biostimulants improves growth, chemical constituents, and yield of head lettuce plant. Middle East Journal of Agriculture Research 7: 1268-1277.

Abdelhamid, M.; Horiuchi, T.; Oba, S. 2004. Composting of rice straw with oilseed rape cake and poultry manure and its effects on faba bean (Vicia faba L.) growth and soil properties. Bioresource Technology 93: 183-189.

Abdelraouf, E.A.A.; Adss, I.A.A.; Dakroury, M.Z. 2016. Effect of salinity on growth and genetic diversity of broad bean (Vicia faba L.) cultivars. Alexandria Science Exchange Journal 37: 467-479.

AL-Bayati, H.J.M.; Kammel, T.J. 2014. Improving growth and yield by application organic fertilizers compared with chemical fertilizers on tow cucumber (Cucumis sativus L.) cultivar which grown under unheated plastic house. Mesopotamia Journal of Agriculture 42: 168- 176.

Atta, M.M.; Abdel-Lattif, H.M.; Absy, R. 2017. Influence of biostimulants supplement on maize yield and agronomic traits. Bioscience Research 14: 604-15. 
Azooz, M.M. 2009. Salt stress mitigation by seed priming with salicylic acid in two faba bean genotypes differing in salt tolerance. International Journal of Agriculture and Biology 11: 343-350.

Bartlett, M.S. 1937. The statistical conception of mental factors. British Journal of Psychology 28: 97-104.

Ben-Hayyim, G.; Vaadiay, Y.; Williams, G.B. 1989. Protein associated with salt adaptation in citrus and tomato cell: Involvement of 26-KD polypeptides. Physiologia Plantarum 77: 332-340.

Bradford, M.M. 1976. A rapid and sensitive method for the quantitation of microgram quantities of protein utilizing the principle of protein-dye binding. Analytical Biochemistry 72 : 248-254.

Broughton, W.J.; Hernandez, G.; Blair, M.; Beebe, S.; Gepts, P.; Vanderleyden, J. 2003. Beans (Phaseolus spp.): model food legumes. Plant and Soil 252: 55-128.

Bulgari, R.; Cocetta, G.; Trivellini, A.; Vernieri, P.; Ferrante, A. 2015. Biostimulants and crop responses: a review. Biological Agriculture and Horticulture 31: 1-17.

Caradonia, F.; Battaglia, V.; Righi, L.; Pascali, G.; La Torre, A. 2019. Plant biostimulant regulatory framework: prospects in Europe and current situation at international level. Journal of Plant Growth Regulation 38: 438-448.

Catalysis. 2014. VIUSID ${ }^{\circledR}$ agro, promotor delcrecimiento. Available at: https://catalysisagro.es/en/agro/ [Accessed Mar 14, 2019]

Chaichi, W.; Djazouli, Z.; Zebib, B.; Merah, O. 2018. Effect of vermicompost tea on faba bean growth and yield. Compost Science \& Utilization 26: 279-285.

Chao, W.S.; Gu, Y.Q.; Pautot, V.; Bray, E.A.; Walling, L.L. 1999. Leucine aminopeptidase RNAs, proteins, and activities increase in response to water deficit, salinity, and the wound signals systemin, methyl jasmonate, and abscisic acid. Plant Physiology 120: 979-992.

Chen, C.; Tao, C.; Peng, H.; Ding, Y. 2007. Genetic analysis of salt stress responses in asparagus bean (Vignaunguiculata L. ssp. Sesquipedalisverdc.). Journal of Heredity 98: 655-665.

Cheruth, J.; Ragupathi, G.; Ashot, K.; Paramasivam, M.; Beemarao, S.; Rajaram, P. 2008. Interactive effects of triadimefon and salt stress on antioxidative status and ajmalicine accumulation in Catharanthus roseus. Acta Physiologiae Plantarum 30: 287-292.

Cucci, G.; Lacolla, G.; Summo, C.; Pasqualone, A. 2019. Effect of organic and mineral fertilization on faba bean (Vicia faba L.). Scientia Horticulturae 243: 338-343.

Dawood, M.G.; Abdel-Baky, Y.R.; El-Awadi, M.E.; Bakhoum, G.S. 2019. Enhancement quality and quantity of faba bean plants grown under sandy soil conditions by nicotinamide and/or humic acid application. Bulletin of the National Research Centre 43: 1-8.

Dawood, M.G.; El-Awadi, M.E. 2015. Alleviation of salinity stress on Vicia faba L. plants via seed priming with melatonin. Acta Biológica Colombiana 20: 223-235.

Dhary, S.I.; Al-Baldawi, M.H.K. 2017. Response of different varieties of faba bean to plant source organic fertilizers. The Iraqi Journal of Agricultural Sciences 1: 1148-1157.

Dulormne, M.; Musseau, O.; Muller, F.; Toribio, A.; Bâ, A. 2010. Effects of $\mathrm{NaCl}$ on growth, water status, N2 fixation, and ion distribution in Pterocarpus officinalis seedlings. Plant and Soil 327: 23-34.
El-Galad, M.A.; Sayed, D.A.; El-Shal, R.M. 2013. Effect of humic acid and compost applied alone or in combination with sulphur on soil fertility and faba bean productivity under saline soil conditions. Journal of Soil Sciences and Agricultural Engineering 4: 1139-1157.

Elnesairi, N.N.B.; Elssalem, M.M.E. 2020. Effect of organic and inorganic fertilizers on faba bean (Vicia faba L.) growth and the response of symbiotic rhizobia with faba bean to some environmental factors in sandy lands. Journal of Pure and Applied Sciences 19: 17-26.

Fekadu, E.; Kibret, K.; Melese, A. 2019. Integrated acid soil management for growth, nodulation, and nutrient uptake of faba bean (Vicia faba L.) in Lay Gayint District, northwestern highlands of Ethiopia. International Journal of Agronomy 2019: 498518.

Freed, R.S.P.; Einensmith, S.; Gutez, S.; Reicosky, D.; Smail, V.W.; Wolberg, P. 1989. User's Guide to MSTAT-C Analysis of Agronomic Research Experiments. Michigan State University, East Lansing, MI, USA.

Gaballah, M.S.; Gomaa, A.M. 2005. Interactive effect of Rhizobium inoculation, sodium benzoate and salinity on performance and oxidative stress in two faba bean varieties. International Journal of Agriculture and Biology 7: 495-498.

Gad, N.; Fekry, M.E.; Abou-Hussein, S.D. 2017. Improvement of Faba bean (Vicia faba L.) productivity by using cobalt and different levels of compost under new reclaimed lands. Middle East Journal of Applied Sciences 7: 493-500.

Gomaa, A.M.; Bahr, A.A.; El-Karamay, M.F. 2002. The bioorganic farming and its effects on nodulation, growth and yield parameters of vetch (Vicia sativa L.). Egyptian Journal of Agronomy 24: 79-92.

Gopinath, K.A.; Saha, S.; Mina, B.L. 2011. Effects of organic amendments on productivity and profitability of bell pepperfrench bean-garden pea system and on soil properties during transition to organic production. Communications of Soil Science and Plant Analysis 42: 2572-2585.

Khalafallah, A.; Tawfik, K.M.; Abd El-Gawad, Z.A. 2008. Tolerance of seven faba bean varieties to drought and salt stresses. Research Journal of Agriculture and Biological Sciences 4: 175-186.

Klute, A. 1986. Methods of Soil Analysis. I. Physical and Mineralogical Methods. 2ed. American Society of Agronomy, Madison, WI, USA

Laemmli, U.K. 1970. Cleavage of structural proteins during the assembly of the head of bacteriophage T4. Nature 227: 680-685.

Larkindale, J.; Huang, B. 2004. Thermotolerance and antioxidant systems in Agrostis stolonifera: involvement of salicylic acid, abscisic acid, calcium, hydrogen peroxide, and ethylene. Journal of Plant Physiology 161: 405-413.

Mahmoud, A.R.; Hafez, M.M.; Abd El-Aal, F.S. 2004. Comparative study for using organic manure as individual and/or mixing it with chemical fertilizer and their effects on the productivity of Vicia faba plants. Journal of Agricultural Science 29: 13451354.

Metwali, E.M.R.; Abdelmoneim, T.S.; Bakheit, M.A.N.; Kadas, M.S. 2015. Alleviation of salinity stress in faba bean (Vicia faba L.) plants by inoculation with plant growth promoting rhizobacteria (PGPR). POJ8: 449-460 
Minhas, P.S.; Ramos, T.B.; Ben-Gal, A.; Pereira, L.S. 2020. Coping with salinity in irrigated agriculture: Crop evapotranspiration and water management issues. Agricultural Water Management 227: 105832.

Munns, R.; Tester, M. 2008. Mechanisms of salinity tolerance. Annual Review of Plant Biology 59: 651-681.

Ouzounidou, G.; Ilias, I.F.; Giannakoula, A.; Theoharidou, I. 2014. Effect of water stress and $\mathrm{NaCl}$ triggered changes on yield, physiology, biochemistry of broad bean (Viciafaba) plants and on quality of harvested pods. Biologia 69: 1010-1017.

Page, A.I.; Miller, R.H.; Keeny, D.R. 1982. Methods of Soil Analysis. II. Chemical and Microbiological Methods. 2ed. American Society of Agronomy, Madison, WI, USA.

Peña, K.; Rodríguez, J.C.; Olivera, D.; Calero, A.; Dorta, R.; Meléndrez, J.; Veloso, Y.F.; Kukurtcu, B. 2018. Effect of the growth promoter VIUSID ${ }^{\circledR}$ agro on the morphophysiological and productive performance of tobacco growth (Nicotian atabacum L.). Journal of Agricultural Science and Technology B 8: 157-167.

Peña, K.; Rodriguez, J.C.; Melendrez, J.F. 2016. The VIUSID ${ }^{\circledR}$ agro an alternative in the increase of the production of tomato (Solanum lycopersicum L.). Caribbean Magazine of Social Sciences 15: 1-10.

Peña, K.; Rodriguez, J.C.; Olivera, D.; Melendrez, J.F.; Rodriguez, L.; Valdez, R.; Rodríguez, L. 2017. Effects of growth promoter on different vegetable crops. International Journal of Development Research 7: 11737-43.

Prabu, K.G.; Uthaya, K.B. 2006. Use of organics for crop production under rainfed situation: a review. Agricultural Reviews 27: 208 -215.

Radi, A.A.; Farghaly, F.A.; Hamada, A.M. 2013. Physiological and biochemical responses of salt-tolerant and salt-sensitive wheat and bean cultivars to salinity. Journal of Biology and Earth Sciences 3: 72-88.
Rady, M.M.; Semida, W.M.; Hemida, K.A.; Abdelhamid, M.T. 2016. The effect of compost on growth and yield of Phaseolus vulgaris plants grown under saline soil. International Journal of Recycling of Organic Waste in Agriculture 5: 311-321.

Rai, V.K. 2002. Role of amino acids in plant responses to stress. Biologia Plantarum 45: 471-478.

Riccardi, F.; Gazeau, P.; Ienne, D.V.; Zivy, M. 1998. Protein changes in responses to progressive water deficit in maize. Plant Physiology 117: 1253-1263.

Shapiro, S.S.; Wilk, M.B. 1965. Analysis of variance test for normality (complete samples). Biometrika 52: 591-611.

Shrivastava, P.; Kumar, R. 2015. Soil salinity: a serious environmental issue and plant growth promoting bacteria as one of the tools for its alleviation. Saudi Journal of Biological Sciences 22: 123-131.

Sibole, J.V.; Cabot C.; Poschenrede, C.; Barcelo, J. 2003. Efficient leaf ion partitioning, an overriding condition for abscisic acid controlled stomatal and leaf growth responses to $\mathrm{NaCl}$ salinization in two legumes. Journal of Experimental Botany 54: 2111-2119.

Snedecor, G.W.; Cochran, W.G. 1989. Statistical Methods. 8ed. Iowa State University Press, Ames, IA, USA.

SPSS Statistics. 2008. SPSS for Windows 17.0. IBM, Armonk, NY, USA.

Van Oosten, M.J.; Pepe, O.; De Pascale, S.; Silletti, S.; Maggio, A. 2017. The role of biostimulants and bioeffectors as alleviators of abiotic stress in crop plants. Chemical and Biological Technologies in Agriculture 4: 1-12.

Yakhin, O.I.; Lubyanov, A.A.; Yakhin, I.A.; Brown, P.H. 2017. Biostimulants in plant science: a global perspective. Frontiers in Plant Science 7: 2049. 